\title{
Comparative Study of Lactation Curves and Milk Quality in Holstein versus Swedish Red and White-Holstein Cross Cows
}

\author{
Diego Pipino, ${ }^{1,2}$, Mónica Piccardi ${ }^{3,4}$, Felipe Lembeye ${ }^{5}$, Nicolás Lopez-Villalobos ${ }^{6} \&$ M. Isabel Vázquez $z^{1,4}$ \\ ${ }^{1}$ Departamento de Reproducción Animal, Facultad de Agronomía y Veterinaria, UNRC, Río Cuarto, Córdoba \\ 5800, Argentina \\ ${ }^{2}$ Veterinaria Pipino, Ucacha, Córdoba 2677, Argentina \\ ${ }^{3}$ Cátedra de Estadística y Biometría, Facultad de Ciencias Agropecuarias, Universidad Nacional de Córdoba, \\ Córdoba 5000, Argentina \\ ${ }^{4}$ Consejo Nacional de Investigaciones Científicas y Técnicas (CONICET), Argentina \\ ${ }^{5}$ Departamento Agropecuario, Gerencia de Abastecimiento, Soprole S.A, San Bernardo, Chile \\ ${ }^{6}$ Institute of Veterinary, Animal and Biomedical Sciences, Massey University, Palmerston North, New Zealand \\ Correspondence: Diego Pipino, Médico Veterinario, Córdoba 165, Ucacha, CP: 2677, Córdoba, Argentina. Tel: \\ 54-935-308-0248. E-mail: dfpipino@gmail.com
}

Received: September 19, 2018 Accepted: October 11, 2018 Online Published: November 3, 2018

doi:10.5539/sar.v8n1p11 URL: https://doi.org/10.5539/sar.v8n1p11

\begin{abstract}
The objective of this study reported in this research paper was to compare the lactation curves of the production of milk, fat, protein, percentages of fat and protein, and somatic cell score in purebred Holstein $(\mathbf{H})$ cows and Swedish Red and White (SRW) - Holstein (SxH) crossbred cows in the south-central region of the province of Cordoba, Argentina. The data set consisted of 32847 herd-test records from 1244 purebred H cows and 310 SRW $\mathrm{x} \mathrm{H}$ crossbred cows, from three commercial dairy farms with cows of first to fifth or more lactations. The curves were modeled using the fourth-order Legendre orthogonal polynomials. In this study, the data of production of milk, fat production, protein production, percentage of fat, percentage of protein and somatic cell score (SCS) were analyzed. Purebred $\mathrm{H}$ cows had significantly higher milk production, more fat production and higher protein production levels than did SxH crossbred cows. However, SxH crossbred cows produced milk that had a higher percentage of fat and a higher percentage protein than did purebred $\mathrm{H}$ cows. In none of the lactations did somatic cell score differ significantly between the two breed groups. The results of our study showed that, SxH crossbred cows had significantly higher percentages of fat and protein; however, purebred $\mathrm{H}$ cows were significantly superior to SxH crossbred cows for the production of 305-d milk, fat, and protein. Mammary health, expressed in SCS, did not differ significantly between the two breed groups. Thus, suggest that crossbreeding Holstein purebred cows with SRW bulls can improve the composition of milk solids without affecting mammary health and, in this way, compensate substantially for any potential loss in the production and/or quality of the milk of the crossbred cows compared to $\mathrm{H}$ purebred cows.
\end{abstract}

Keywords: lactation curves, crossbreeding, dairy cows, Holstein, Swedish Red and White

\section{Introduction}

Holstein $(\mathrm{H})$ cattle are the most prominent breed in the world due to their high production of milk per cow. In many countries milk production per cow has more than doubled in the last 40 years, this has been achieved by genetic selection and improvement of management practices and feeding (Oltenacu \& Broom, 2010). The increase in milk yield has been accompanied by declining fertility, increasing leg and metabolic problems and declining longevity (Oltenacu \& Broom, 2010).

Milk payments for the producers in most of the countries put a major emphasis on milk solids, rather than on milk volume, which has resulted in fewer competitive advantages for the $\mathrm{H}$ breed in comparison with other breeds (Heins, Hansen \& Seykora, 2006). Other authors have indicated that crossbreed cows were significantly superior to purebred $\mathrm{H}$ in the production of solids, although they were not for milk production (Dechow, Rogers, Cooper, Phelps \& Mosholder, 2007; Swalve, Bergk \& Solms-Lich, 2008). 
Improvements in fertility, calving ease, longevity, and milk composition have been cited by dairy producers as reasons for crossbreeding (Weigel \& Barlass, 2003). Somatic cell count (SCC) is a reliable indicator of the health of the mammary gland (Schukken, Wilson, Welcome, Garrison-Tikofsky \& Gonzalez, 2003). Numerous studies have documented the importance of crossbreeding in the dairy industry (Fohrman, McDowell, Matthews \& Hilder, 1954; Rincón, Schermerhorn, McDowell \& McDaniel, 1982; Touchberry, 1992). Recently, Heins and Hansen (2012) have demonstrated that crossbred cows had lower SCC than did purebred H cows.

The potential for raising the profitability (López-Villalobos, Garrick, Holmes, Blair \& Spelman, 2000; Coffey, Horan, Evans \& Berry, 2016), fertility (Auldist, Pyman, Grainger \& Macmillan, 2007), and longevity (Harris, Holmes, Winkelman \& Xu, 1996) in commercial dairy herds has driven the interest in crossbreeding. Heterosis (or hybrid vigor) from crossbreeding can cause a $6.5 \%$ increase in production and at least a $10 \%$ increase in fertility, disease resistance, and the productive life of dairy cows, compared to the average of the parental breeds (Hansen, Heins \& Seykora, 2005 ). Production and functional traits should be assessed simultaneously so that the total economic merit of the dairy cows, rather than milk production, only, can be evaluated (Heins \& Hansen, 2012).

Vance, Ferris, Elliott, McGettrick \& Kilpatrick (2012) suggested that crossbreeding is a mating system that is important to all levels of management. The same results were observed in the studies by Kargo, Madsen \& Norberg (2012), and Malchiodi, Cecchinato \& Bittante (2014). Recent research by Buckley, Lopez-Villalobos \& Heins (2014) has clearly illustrated the benefits of crossbreeding, using a range of modern breeds, and in both low-cost (grazing-based) systems and high-input environments such as confined production.

An understanding of the shape of lactation curves is crucial for decision-making in dairy farms (Macciota, Vicario \& Cappio-Borlino, 2005) at the population and individual levels (Vargas, Koops, Herrero \& Van Arendonk, 2000). Modelling of the lactation curve could be useful to evaluate the effect of factors influencing milk production such as number of days in lactation, lactation number (Silvestre, Martins, Santos, Ginja \& Colaço, 2009), the calving season (Catillo, Macciotta, Carretta \& Cappio-Borlino, 2002), and the level of production (Mostert, Theron \& Kanfer, 2003).

Given that, in Argentina, most of the dairy cows are H (Demarco, 2010), and that the phenomena described above have been observed in various countries, the possibility of using crossbreeding to improve profitability for dairy producers is important. Thus, our working hypothesis was that crossbreeding can increase the percentages of milk solids, aid in achieving production similar to that obtained from purebred $\mathrm{H}$ cows. For our study, we chose the Swedish Red and White (SRW), which originated from the Nordic selection system. This breeding progam emphasizes not only the productive traits, but also emphasizes selection based on health, fertility, and conformation traits (Philipsson, Jansson \& Brannang, 1975; Sørensen, Norberg, Peterson \& Christensen, 2008). Compared to H cows, SRW cows are smaller, have lower milk production with higher percentages of fat and protein, better fertility, and have a more compact body structure, which satisfies the interests who has an interest in producing meat as a by-product of dairy production, and seeks a cow that has conformation traits that are most suited to their production systems.

The objective of this study was to compare the lactation curves of the production of milk, fat, protein, percentages of fat and protein and somatic cell score in purebred $\mathrm{H}$ cows and SRW-H (SxH) crossbred cows in the south-central region of the province of Cordoba, Argentina.

\section{Materials and Methods}

\subsection{Data}

The observation and data collection period was from 1 January 2008 to 31 December 2013 (6 yr). We worked with three commercial dairy farms in the area of Ucacha, in south-central Cordoba, Argentina. Dairy farm 1, San Andres $\left(33^{\circ} 57^{\prime} 38,41^{\prime \prime} \mathrm{S}\right.$ and $\left.63^{\circ} 30^{\prime} 49,85^{\prime} \mathrm{W}\right)$ had 120 dairy cows, Dairy farm 2, JE Dairy Farm $\left(33^{\circ} 03^{\prime} 33\right.$,

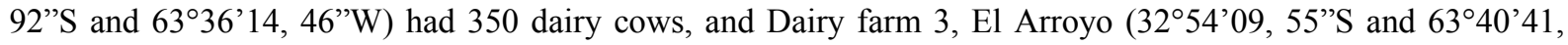
53 ”'W) had 180 dairy cows.

For more than 20 years, the farms have performed artificial insemination using cryopreserved semen. Before the study began, the dairy farms used the $\mathrm{H}$ breed and most of the genetics implemented came from the USA. The cryopreserved semen from the SRW bulls was imported from Sweden, and the bulls were selected mainly for functional traits, with the objective of reducing body size, improving calving ease, fertility and milk quality, increasing the percentage of fat and protein in the milk, and reducing the somatic cell count (SCC). Bulls were not selected for the capacity to transmit high milk production because this trait would be provided by the genetic load from the $\mathrm{H}$ breed. The study included purebred $\mathrm{H}$ cows (primiparous and multiparous) and $\mathrm{SxH}$ crossbred 
cows that had their first calving in 2008 .

On each farm, two daily milkings were performed within a semi-stabled feeding system, which was based on alfalfa pasture feeding supplemented with wintergreens and silo corn. In addition, the diet was systematically supplemented with regional by-products, expeller and flours, depending on the time of year. The dairy farms were monitored through weekly visits. Dairy controls of two consecutive milkings (morning and afternoon) were performed each month. In the months that milk composition and SCC were analyzed, the samples were processed by the LABVIMA S.A laboratory (Villa María, Argentina). The controls that were performed since the calving date until 305 days in milk (DIM) were included in the analysis. When the day of the control was on the day of calving (day 0), in our analysis, the control day was considered day -one.

In this study, the data of production of milk, fat production, protein production, percentage of fat, percentage of proteinand SCC were analyzed. All of the cows that had < 60 DIM were excluded from the analysis, and the data that indicated percentages of fat and protein that were $<1 \%$ or $>10 \%$ were excluded from the analysis. Somatic cell count (SCC) was transformed to somatic cell score (SCS) as follows: $\mathrm{SCS}=\log _{2}$ (SCC).

The data were grouped based on the cow's farm of origin, and the number and year of the calving. In addition, based on the seasonal climate of southern Cordoba, and the distribution of the dates of calving, the data were grouped into one of three seasons: Season 1 (Autumn): February, March, April; Season 2 (Winter): May, June, July; and Season 3 (Spring-Summer): August, September, October, November, December, January. In addition, first, second, third, fourth, and fifth or more lactations were assigned to groups. A summary of the population studied is presented in Table 1 .

Table 1. Number of herd-test records, and cows in the study population by breed and herd

\begin{tabular}{lccccccccc}
\hline & \multicolumn{3}{c}{ Milk Yield } & \multicolumn{2}{c}{ Fat Yield } & \multicolumn{2}{c}{ Protein yield } & \multicolumn{2}{c}{ Somatic cell count } \\
\hline Breed & Herd & Herd -test records & Cows & Herd -test records & Cows & Herd -test records & Cows & Herd -test records & Cows \\
\hline $\mathrm{H}$ & 1 & 7628 & 356 & & & & & & \\
& 2 & 17417 & 774 & 13854 & 767 & 12007 & 721 & 13180 & 755 \\
& 3 & 2356 & 114 & & & & & & \\
$\mathrm{SxH}$ & 1 & 1747 & 109 & & & & & & \\
& 2 & 3136 & 168 & 2491 & 167 & 2365 & 166 & 2491 & 167 \\
& 3 & 563 & 33 & & & & & & \\
\multicolumn{2}{c}{ Total } & 32847 & 1554 & 16345 & 934 & 14372 & 887 & 15671 & 922 \\
\hline
\end{tabular}

H: Holstein.

SxH: Swedish Red and White-Holstein.

\subsection{Lactation Curves}

The curves were modeled using the fourth-order Legendre orthogonal polynomials of Kirkpatrick, Lofsvold \& Bulmer (1990). Considering $Y_{t}$ as the level of production for the trait, measured in days $(t)$ of the lactation since the calving, the fourth-order polynomial was defined as follows:

$$
Y_{t}=\alpha_{0} \times P_{0}+\alpha_{1} \times P_{1}+\alpha_{2} \times P_{2}+\alpha_{3} \times P_{3}+\alpha_{4} \times P_{4}
$$

where $\alpha_{\mathrm{i}}$ is the estimated regression coefficient, $P_{i}$ is the function normalized to $x$, which is standardized to unit of time described by: $x=-1+2\left(\left(t-t_{\min }\right) /\left(t_{\max }-t_{\min }\right)\right)$, where $t_{\min }=$ day 1 and $t_{\max }=305 \mathrm{~d}$, which converted the herds-test records between $1 \mathrm{~d}$ and $305 \mathrm{~d}$ to range between -1 and +1 , respectively (Schaeffer, 2004).

The fourth-order Legendre polynomial of functions standardized to the unit of time and the regression coefficients $\alpha_{i}$, was calculated as follows:

$$
P_{0}(t)=1, \quad P_{1}(t)=x, P_{2}(t)=1 / 2\left(3 x^{2}-1\right), \quad P_{3}(t)=1 / 2\left(5 x^{3}-3 x\right), \quad P_{4}(t)=1 / 8\left(35 x^{4}-30 x^{2}+15\right) .
$$

The polynomial equations included the fixed regression coefficients and the random regression coefficients of the population as the deviation of the fixed effects of the population for each combination of cow-lactation number. For cow-lactation " $i$ " in DIM " $t$ ", the equation is rewritten as follows:

$$
Y_{t i}=\left(\beta_{0} P_{o}+\beta_{1} P_{1}+\ldots \beta_{4} P_{4}\right)+\alpha_{0 i} P_{0 i}+\alpha_{l i} P_{l i}+\ldots \ldots \alpha_{4 i} P_{4 i}+e_{t i}
$$

where $\beta$ 's are the fixed regression coefficients of the population, $\alpha$ 's are the random regression coefficients for 
each combination of cow-lactation number, and $e_{(\mathrm{it})}$ is the random error associated with each observation of day $t$ and cow-lactation $i$.

In addition to the fourth-order Legendre polynomial, polynomials of order 2 and 3 were also tested. The decision to use a fourth-order polynomial was based on the smallest 'Akaike's Information Criterion' (AIC) value (Akaike 1973), which was achieved with polynomial of order 4. The fourth-order Legendre polynomial was used to predict milk, fat, and protein production, percentage of fat, percentage of protein, and SCS because the Akaike's Information Criterion' (AIC) value (Akaike 1973) was lower than that of the second- and third-order polynomials.

\subsection{Statistical Analysis}

Cumulative production of milk, fat, protein, and mean production of fat and protein of each cow were estimated using the polynomial equation as the sum from day 1 to actual lactantion length thougt 305 days. The mean SCS was estimated based on the orthogonal polynomial function. PROC MIXED (SAS®, Versión 9.4, 2014) was used to calculate the least squares mean and the standard error for each variable of the lactation curve, the predictions of accumulated milk, fat, and protein production, the percentages of fat and protein, and the average SCS. All estimates were derived from the following statistical linear model:

$$
y_{i j k}=\mu+H Y S_{i}+R_{j}+L_{k}+R L_{j k}+v_{l}+e_{i j k}
$$

where $\mathrm{y}_{\mathrm{ijk}}$ is milk production, fat production, protein production, percentage of fat, percentage of protein, or the average SCS of the dairy farm-year-season i, breed $\mathrm{j}$, and the lactation number $\mathrm{k} ; \mu$ is the population average, $\mathrm{HYS}_{\mathrm{i}}$ is the random effect of the contemporary group, which was defined as cows that occur in the same dairy farm, in the same year, and in the same season ( $i=1,2 \ldots 54) ; R_{j}$ is the fixed effect of breed group $(j=H$ and $\mathrm{SxH}) ; \mathrm{L}_{\mathrm{k}}$ is the fixed effect of lactation number $\mathrm{k}(\mathrm{k}=1,2 \ldots 5) ; \mathrm{RL}_{\mathrm{jk}}$ is the interaction between breed $\mathrm{j}$ and lactation number $\mathrm{k} ; \mathrm{v}_{\mathrm{l}}$ is the random effect for each cow $1(\mathrm{l}=1,2 \ldots . .1554)$, and $\mathrm{e}_{\mathrm{ijk}}$ is the residual random error associated with the observation $\mathrm{y}_{\mathrm{ijk}}$.

\section{Results}

In general, the predictive capacity of the fourth-order Legendre polynomial was high for all traits evaluated $(\mathrm{r} \geq$ 0.94) (data not shown), and the shape of the lactation curve was more flexible than were those derived from the other Legendre polynomials. The regression coefficient estimates that describe the lactation curves for the production of milk, fat, and protein, average SCS, and the percentages of fat and protein of the two breed groups $(\mathrm{H}$ and $\mathrm{SxH})$ are shown in SupplementariesTables S1 through S6.

In each of the five consecutive lactations, purebred $\mathrm{H}$ cows had significantly $(\mathrm{p}<0.05)$ higher milk production at the start of lactation (intercept) than did the crossbred SxH cows. In lactations 2, 3, and 4, purebred $\mathrm{H}$ cows produced significantly more fat than did $\mathrm{SxH}$ crossbred cows. In lactations $1,2,3$, and 4, purebred $\mathrm{H}$ cows had significantly higher protein production levels than did crossbred $\mathrm{SxH}$ cows $(\mathrm{p}<0.01)$. In none of the lactations did SCS differ significantly between the two breed groups. In lactations $1,2,3(\mathrm{p}<0.01)$, and $5(\mathrm{p}<0.05)$, crossbred SxH cows produced milk that had a higher percentage of fat than did purebred H cows (Supplementary Table 5). In each of the five lactations, crossbred SxH cows produced milk that had a significantly higher percentage of protein than did purebred $\mathrm{H}$ cows $(\mathrm{p}<0.05)$.

In all of the adult cows (second to fifth lactation), milk production increased from day 1 after calving until 55-60 d postpartum, then gradually decreased until the end of lactation (Figure 1). However, in all of the cows of both breeds, the lactation curve of the first lactation differed from those observed in adult cows (Figure 1). In purebred $\mathrm{H}$ cows, the curve of the first lactation was similar to the curves of adult cows, except that it had a very smooth peak at $80 \mathrm{~d}$ postpartum, followed by a more slighter and gradual decline until the end of lactation. In the first lactation of the crossbred SxH cows, the increase in production occurred at $92 \mathrm{~d}$ postpartum, and the typical decline was not observed, although milk production continued until the last days of the lactation, resembling a plateau, from where a slight decrease in production occurred. 
a

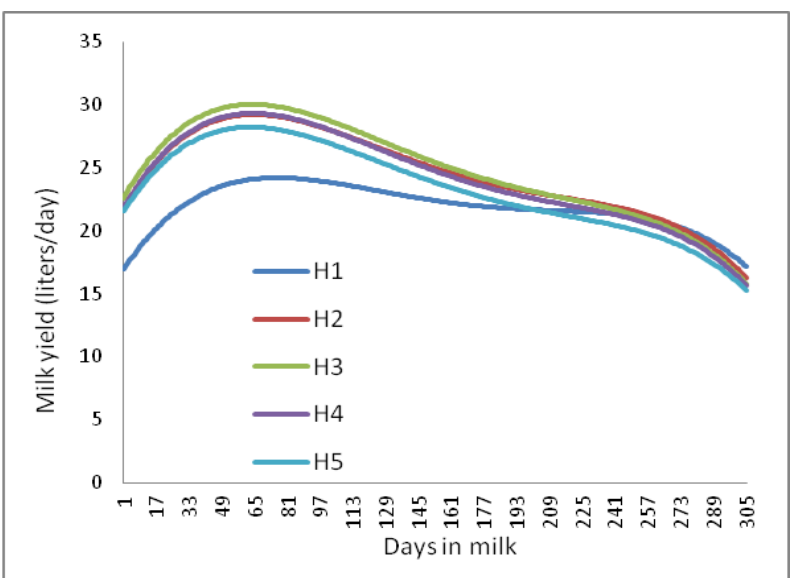

b

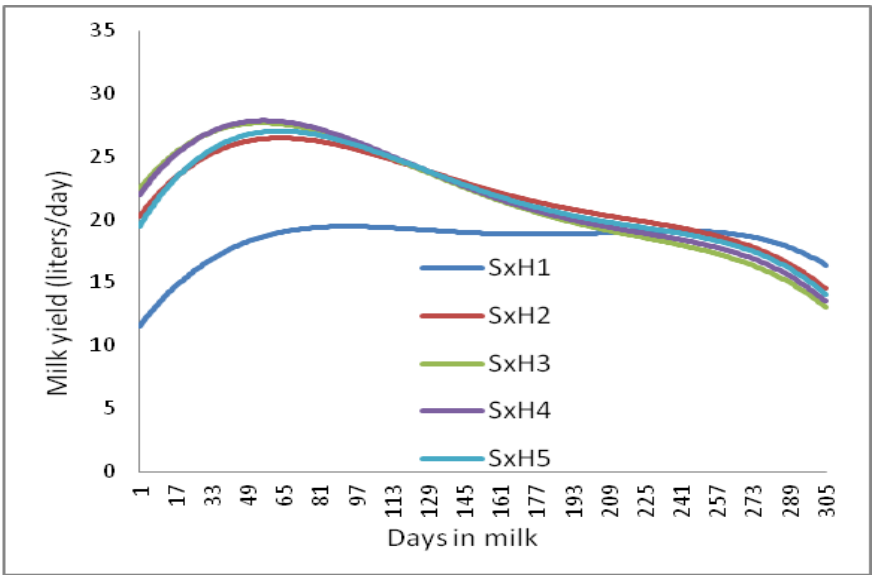

Figure 1. Prediction for milk production (liters/d), from calving until $305 \mathrm{~d}$ of lactation (days in milk), in consecutive lactations (H1 to H5) in Holstein (H) cows (a) and (SxH1 to SxH5) in Swedish Red and

White-Holstein ( $\mathrm{SxH})$ crossbred cows (b)

The lactation curves for fat production, protein production, average SCS, percentage of fat, and percentage of protein are shown in Figures 2-3.

1a

$1 b$
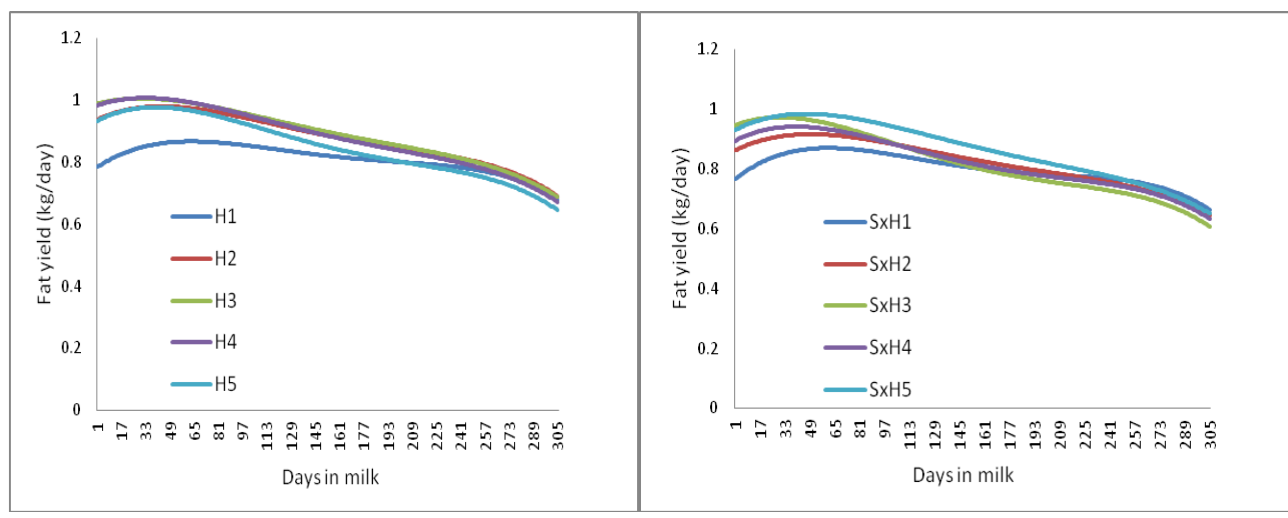

$2 \mathrm{a}$

$2 b$
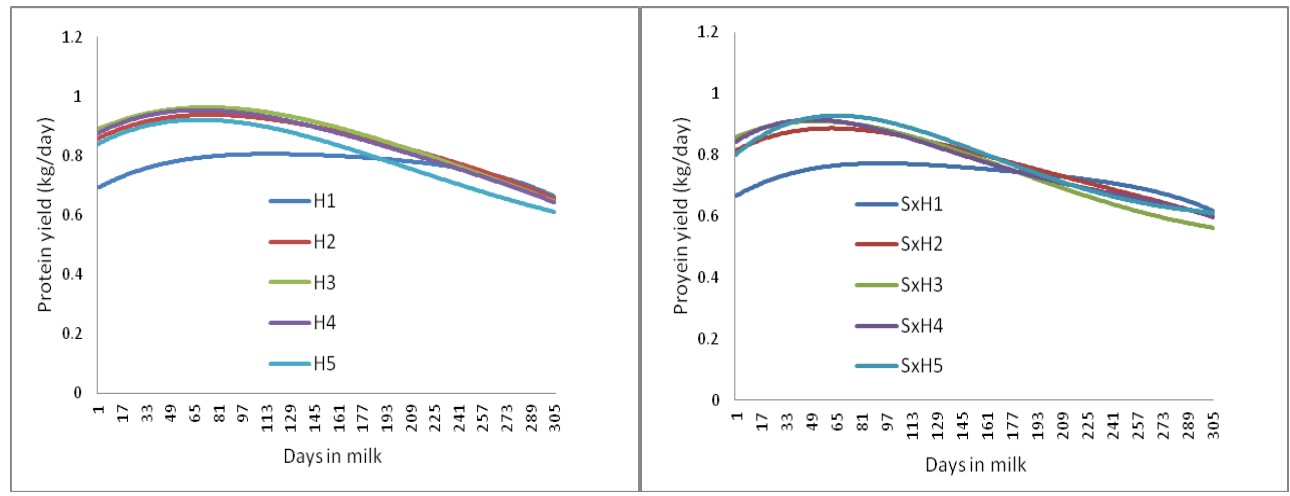
$3 \mathrm{a}$

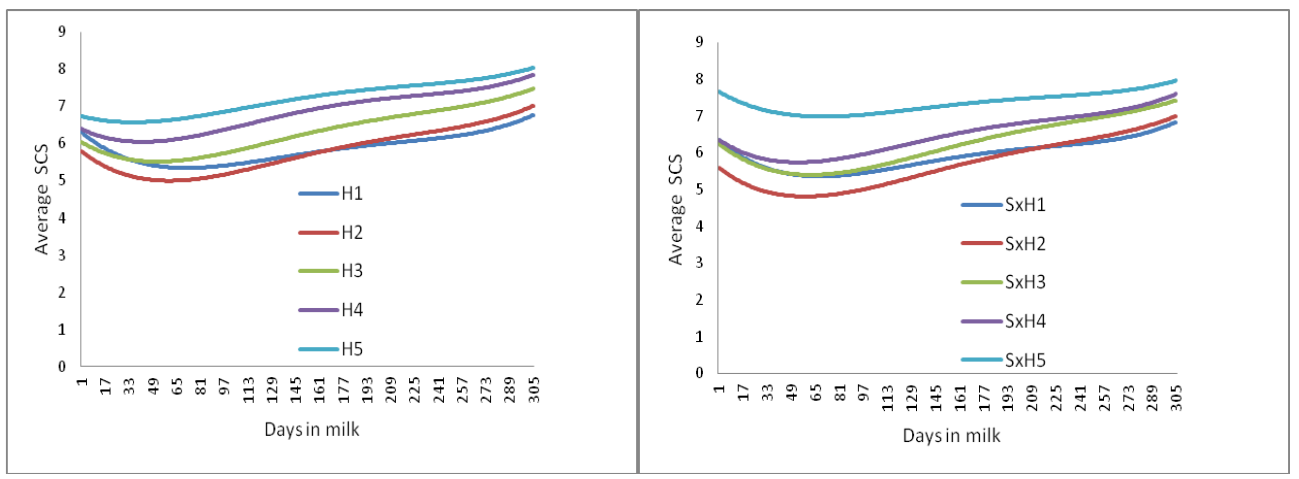

Figure 2. Prediction for fat production (1) $(\mathrm{kg} / \mathrm{d})$, protein production (2) $(\mathrm{kg} / \mathrm{d})$, andaverage SCS (3) from calving until $305 \mathrm{~d}$ of lactation (days in milk), in consecutive lactations (H1 to H5) in Holstein (H) cows (a) and (SxH1 to $\mathrm{SxH} 5)$ in Swedish Red and White-Holstein (SxH) crossbred cows (b)

a

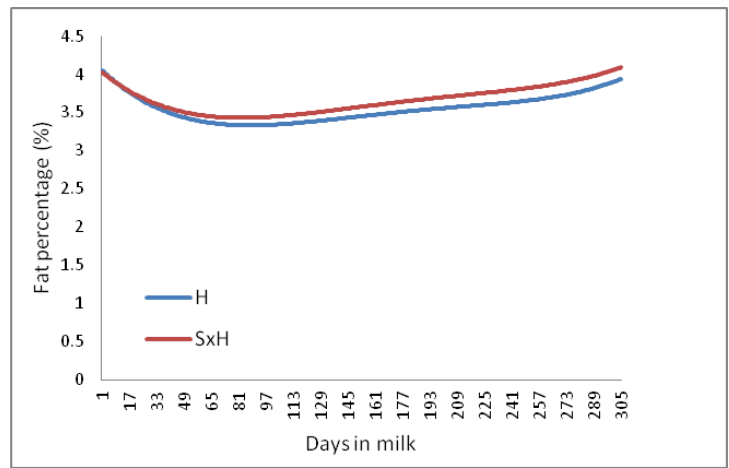

b

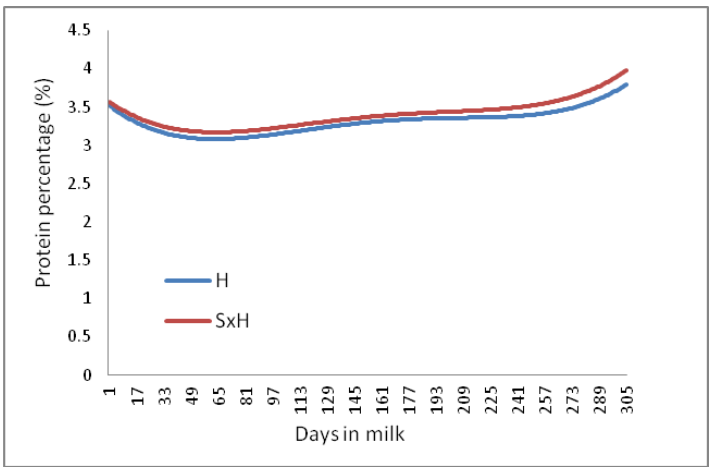

Figure 3. Prediction of the fat percentage (a) and protein percentage (b) from calving until 305 d of lactation (days in milk) in Holstein $(\mathrm{H})$ cows and Swedish Red and White-Holstein ( $\mathrm{SxH})$ crossbred cows

Table 2 shows the predictions of the least squares mean for milk production, fat production, protein production, average SCS, percentage of fat, and percentages of protein. Milk production to $305 \mathrm{~d}$ was significantly $(\mathrm{p}<0.01)$ higher in purebred $\mathrm{H}$ cows $(6205 \mathrm{~L})$ than it was in crossbred $\mathrm{SxH}$ cows $(5505 \mathrm{~L})$. The differences were significant $(\mathrm{p}<0.01)$ in lactations $1,2,3$, and 4 .

Table 2. Predictions of accumulated productions (mean \pm sem) of milk, fat, and protein, average somatic cell score (SCS), and percentages of fat and protein in each lactation, modeled with the fourth-order Legendre polynomial for Holstein $(\mathrm{H})$ cows and Swedish Red and White-Holstein $(\mathrm{SxH})$ crossbred cows

\begin{tabular}{llllllll}
\hline \multirow{2}{*}{ Breed } & $\begin{array}{l}\text { Lactation } \\
\text { Number }\end{array}$ & $\begin{array}{l}\text { Milk } \\
\text { production }\end{array}$ & $\begin{array}{l}\text { Fat } \\
\text { production }\end{array}$ & $\begin{array}{l}\text { Protein } \\
\text { Production }\end{array}$ & $\begin{array}{l}\text { Average } \\
\text { SCS }\end{array}$ & $\begin{array}{l}\text { Fat } \\
\text { percentage }\end{array}$ & $\begin{array}{l}\text { Protein } \\
\text { percetage }\end{array}$ \\
\hline $\mathrm{H}$ & & $6205 \pm 53^{\mathrm{a} * *}$ & $226 \pm 2^{\mathrm{a} * *}$ & $220 \pm 2^{\mathrm{a}}$ & $6.39 \pm 0.04^{\mathrm{a}}$ & $3.55 \pm 0.01^{\mathrm{b} * *}$ & $3.31 \pm 0.01^{\mathrm{b} * *}$ \\
$\mathrm{SxH}$ & & $5505 \pm 110^{\mathrm{b} * *}$ & $213 \pm 4^{\mathrm{b} * *}$ & $201 \pm 4^{\mathrm{b} * *}$ & $6.33 \pm 0.09^{\mathrm{a}}$ & $3.67 \pm 0.03^{\mathrm{a} * *}$ & $3.40 \pm 0.03^{\mathrm{a} * *}$ \\
$\mathrm{H}$ & 1 & $5806 \pm 72^{\mathrm{a} * *}$ & $218 \pm 2^{\mathrm{a}}$ & $208 \pm 3^{\mathrm{a} * *}$ & $5.85 \pm 0.06^{\mathrm{a}}$ & $3.60 \pm 0.01^{\mathrm{b} * *}$ & $3.30 \pm 0.01^{\mathrm{b} * *}$ \\
$\mathrm{SxH}$ & 1 & $5173 \pm 103^{\mathrm{b} * *}$ & $213^{\mathrm{a}} 4^{\mathrm{a}}$ & $195 \pm 4^{\mathrm{b} * *}$ & $5.92 \pm 0.10^{\mathrm{a}}$ & $3.76 \pm 0.02^{\mathrm{a} * *}$ & $3.41 \pm 0.02^{\mathrm{a} * *}$ \\
$\mathrm{H}$ & 2 & $6520 \pm 75^{\mathrm{a} * *}$ & $235 \pm 3^{\mathrm{a} * *}$ & $229 \pm 3^{\mathrm{a} * *}$ & $5.78 \pm 0.06^{\mathrm{a}}$ & $3.55 \pm 0.01^{\mathrm{b} * *}$ & $3.33 \pm 0.01^{\mathrm{b} * *}$ \\
$\mathrm{SxH}$ & 2 & $5714 \pm 126^{\mathrm{b} * *}$ & $210 \pm 6^{\mathrm{b} * *}$ & $203 \pm 5^{\mathrm{b} * *}$ & $5.67 \pm 0.12^{\mathrm{a}}$ & $3.65 \pm 0.03^{\mathrm{a} * *}$ & $3.44 \pm 0.02^{\mathrm{a} * *}$ \\
$\mathrm{H}$ & 3 & $6529 \pm 79^{\mathrm{a} * *}$ & $234 \pm 3^{\mathrm{a} * *}$ & $230 \pm 3^{\mathrm{a} * *}$ & $6.31 \pm 0.06^{\mathrm{a}}$ & $3.55 \pm 0.02^{\mathrm{b} * *}$ & $3.33 \pm 0.01^{\mathrm{b} *}$ \\
$\mathrm{SxH}$ & 3 & $5616 \pm 164^{\mathrm{b} * *}$ & $209 \pm 7^{\mathrm{b} * *}$ & $200 \pm 7^{\mathrm{b} * *}$ & $6.23 \pm 0.16^{\mathrm{a}}$ & $3.66 \pm 0.06^{\mathrm{a} * *}$ & $3.40 \pm 0.03^{\mathrm{a} *}$ \\
$\mathrm{H}$ & 4 & $6253 \pm 79^{\mathrm{a} * *}$ & $228 \pm 3^{\mathrm{a}}$ & $223 \pm 3^{\mathrm{a} *}$ & $6.83 \pm 0.07^{\mathrm{a}}$ & $3.54 \pm 0.02^{\mathrm{a}}$ & $3.31 \pm 0.01^{\mathrm{b} *}$ \\
$\mathrm{SxH}$ & 4 & $5412 \pm 204^{\mathrm{b} * *}$ & $211 \pm 9^{\mathrm{a}}$ & $202 \pm 8^{\mathrm{b} *}$ & $6.48 \pm 0.19^{\mathrm{a}}$ & $3.62 \pm 0.05^{\mathrm{a}}$ & $3.40 \pm 0.03^{\mathrm{a} *}$ \\
$\mathrm{H}$ & 5 & $5915 \pm 77^{\mathrm{a}}$ & $217 \pm 3^{\mathrm{a}}$ & $211 \pm 3^{\mathrm{a}}$ & $7.20 \pm 0.07^{\mathrm{a}}$ & $3.53 \pm 0.02^{\mathrm{b} *}$ & $3.27 \pm 0.01^{\mathrm{b} *}$ \\
$\mathrm{SxH}$ & 5 & $5610 \pm 263^{\mathrm{a}}$ & $221 \pm 10^{\mathrm{a}}$ & $207 \pm 9^{\mathrm{a}}$ & $7.35 \pm 0.22^{\mathrm{a}}$ & $3.66 \pm 0.05^{\mathrm{a} *}$ & $3.36 \pm 0.04^{\mathrm{a} *}$ \\
\hline
\end{tabular}

${ }^{\mathrm{a}, \mathrm{b}}$ Different superscripts in each column indicate significant differences between breeds in each lactation $(* \mathrm{P}<0.05, * * \mathrm{P}<0.01)$. 
For fat production, overall, purebred $\mathrm{H}$ cows produced $13 \mathrm{~kg}$ more fat than did crossbred $\mathrm{SxH}$ cows $(\mathrm{p}<0.01)$. In lactations 2 and 3 , the differences between breeds were significant $(p<0.01)$. There were no significant differences in fat produced, even though purebred $\mathrm{H}$ cows produced $5 \mathrm{~kg}$ more fat in the first lactation and $17 \mathrm{~kg}$ more in the fourth lactation than did the crossbred SxH cows and, in the fifth lactation, crossbred SxH cows produced $4 \mathrm{~kg}$ more fat than did purebred $\mathrm{H}$ cows.

Overall, the percentage of fat in the milk of purebred $\mathrm{H}$ cows was significantly $(\mathrm{p}<0.01)$ less than that of crossbred SxH cows. The difference was highly significant $(\mathrm{p}<0.01)$ in lactations 1,2 , and 3 , and marginally significant $(\mathrm{p}<0.05)$ in the fifth lactation.

Protein production was significantly $(\mathrm{p}<0.01)$ higher in purebred $\mathrm{H}$ cows $(220 \mathrm{~kg})$ than it was in crossbred $\mathrm{SxH}$ cows $(201 \mathrm{~kg})$. The differences were highly $(\mathrm{p}<0.01)$ significant in each of the first three lactations, and marginally ( $>>0.05)$ significant in lactation 4.

Overall, the percentage of protein in milk was significantly $(\mathrm{p}<0.01)$ lower in purebred $\mathrm{H}$ cows than it was in crossbred SxH cows. Differences were highly $(\mathrm{p}<0.01)$ significant in lactations 1 and 2, and marginally $(\mathrm{p}<0.05)$ significant in lactations 3,4 , and 5 .

In both breeds, SCS increased as lactation progressed. The lowest SCS was 5.67 in lactation 2, and the highest was 7.35 in lactation 5. In none of the lactations did SCS differ significantly between the two breeds.

\section{Discussion}

The objective of this study was to compare the lactation curves of the production of milk, fat, protein, percentages of fat and protein, and SCS in purebred $\mathrm{H}$ cows and SxH crossbred cows in the south-central region of the province of Cordoba, Argentina.

The relationship between the mathematical properties and the shape of lactation curves was analyzed by Macciota et al. (2005) using various common adjustments, who concluded that the orthogonal polynomial models allow the most curvatures and, therefore, are the most flexible model.

Differences between breeds in milk production were constant throughout the first four lactations, in which the crossbred SxH cows produced 11-14\% less milk than did the purebred $\mathrm{H}$ cows. In the fifth lactation, the difference was 5\%. Those results are similar to those reported by Heins and Hansen (2012), who studied five consecutive lactations in purebred H and crossbred SxH cows. Similar to our study, Heins et al. (2006) and Hazel, Heins \& Hansen (2017), who studied only first lactations, reported that purebred H cows produced more of milk than did crossbred cows. In our study, the results in the second lactation were similar to those obtained by Swalve et al. (2008); however, unlike ours, in their study, they found that crossbred SxH cows were superior to purebred $\mathrm{H}$ cows in the first lactation. Also, unlike our study, Laborde, Dutour, Lopez-Villalobos, Meikle \& Chilibroste (2014), who studied cows of first, second and third lactations, found that SxH crossbreed cows produced more of milk than did purebreed $\mathrm{H}$ cows.

In our study, in the first lactation, fat production did not differ significantly between the two breeds, which might explain why crossbred SxH cows produced the highest percentages of fat, which was evident in a study by Heins et al. (2006) and Hazel et al. (2017) in the USA, but not in the studies, by Swalve et al. (2008) in Germany, as by Laborde et al. (2014), in Uruguay, where crossbred SxH cows produced more and a higher percentage of fat than did purebred $\mathrm{H}$ cows.

Protein production in the first lactation was similar to that reported by Heins et al. (2006), who found that protein production was higher in purebred $\mathrm{H}$ cows than it was in crossbred SxH cows. Unlike our study, however, Swalve et al. (2008) found that crossbred SxH cows had higher protein production than did purebred $\mathrm{H}$ cows. In addition, our results contrast those of Laborde et al. (2014) and Hazel et al. (2017), who found that did not differ significantly between the purebred $\mathrm{H}$ and crossbred SxH cows. In our study and that of Heins and Hansen (2012), in each of the five lactations, the percentage of protein in milk was higher in crossbred SxH cows than it was in purebred $\mathrm{H}$ cows.

For the average SCS, our results coincide with the results obtained by Heins and Hansen (2012), average SCS did not differ significantly between the two breeds in lactations 2,3 , and 4; however, unlike our study, they found that crossbred SxH cows had a lower average SCS than did purebred $\mathrm{H}$ cows. In addition, our results contrast those of Swalve et al. (2008), who found that, in lactation 1 and lactation 2, crossbred SxH cows had higher average SCS than did purebred H cows.

The predictions from the least squares mean for milk production to $305 \mathrm{~d}$ did not adjust for the difference in days open (DO) in the cows in the two breed groups. Lee, VanRaden, Norman, Wiggans \& Meinert (1997) reported 
that DO had a significant effect on production; specifically, that fewer DO reduced in production, and an increase in production DO. Therefore, if the appropriate adjustment for DO were applied, the production of crossbred SxH cows might have been closer to the production of purebred $\mathrm{H}$ cows (Heins et al., 2006). Our study did not assess production efficiency, which is the production of milk or milk solids per unit of food consumption (López-Villalobos et al., 2008), even though crossbred SxH cows are smaller than purebred H cows, which reduces maintenance costs. If the production-versus-consumed adjustment of production was included, production differences between breeds could be reduced further. The advantages of those features can compensate substantially for any potential loss in the production of the crossbreed cows compared to the purebred $\mathrm{H}$ cows. Production and functional traits should be assessed simultaneously to measure dairy cow performance broadly, rather than by measuring milk production, only.

The results of our study are of importance to the region of Cordoba and Argentina, as well as for other countries since the study used commercial herds in semi-pastoral production systems, rather than experimental herds. In addition, to our knowledge, similar studies have not been performed in Argentina. Publications on the subject, found in the literature, come from various countries, which have established production systems and different levels of management to those used in Argentina. In addition, our results are similar to those of others (Heins et al., 2006; Swalve et al., 2008; Heins \& Hansen, 2012), who reported that SxH crossbred cows produced in consecutive lactations from $90 \%$ to $94 \%$ of what purebred $\mathrm{H}$ cows produced, but with higher percentages of fat $(+3,4 \%)$ and protein $(+2,7 \%)$.

It is important to emphasize that, at this time, both producers, technical consultants, and leaders in the dairy industry agree that it is important to measure the performance of the dairy cow comprehensively, and not solely on milk production. Further research will help to determine whether crossbreeding can be a cost-effective tool for improving the production, fertility, and survival in dairy cattle.

Under the conditions of our study, $\mathrm{SxH}$ crossbred cows had significantly higher percentages of fat and protein to $305 \mathrm{~d}$ than purebred $\mathrm{H}$ cows; however, purebred $\mathrm{H}$ cows were significantly superior to SxH cross cows for the production of 305-d milk, fat, and protein. Mammary health, expressed in SCS, did not differ significantly between the two breed groups.

The results suggest that crossbreeding purebred Holstein cows with SRW bulls can improve the composition of milk solids without affecting mammary health and, in this way, compensate substantially for any potential loss in the production and/or quality of the milk of the crossbred cows compared to purebred $\mathrm{H}$ cows.

\section{Acknowledgment}

The authors are especially grateful to the owners/ managers of the 3 Ucacha, Argentina dairy herds, who willingly provided data from their cows. Without their cooperation, these studies would not have been possible.

\section{References}

Akaike, H. (1973). Information theory as an extension of the maximum likelihood principle. In Proceedings of the 2nd International Symposium on Information Theory. Akademiai Kiado, Budapest Hungary. 267-281.

Auldist, M. J., Pyman, M. F. S., Grainger, C., \& Macmillan, K. L. (2007). Comparative reproductive performance and early lactation productivity of Jersey $\times$ Holstein cows in predominantly Holstein herds in a pasture-based dairying system. Journal of Dairy Science, 90, 4856-4862. https://doi.org/10.3168/jds.2006-869

Buckley, F., Lopez-Villalobos, N., \& Heins, J. B. (2014). Crossbreeding: implications for dairy cow fertility and survival. Animal, 8(suppl 1), 122-133. https://doi:10.1017/S1751731114000901

Catillo, G., Macciotta, N. P. P., Carretta, A., \& Cappio-Borlino, A. (2002). Effects of age and calving season on lactation curves of milk production traits in Italian water buffaloes. Journal of Dairy Science, 85, 1298-1306. https://doi.org/10.3168/jds.S0022-0302(02)74194-5

Coffey, E. L., Horan, B., Evans, R. D., \& Berry, D. P. (2016). Milk production and fertility performance of Holstein, Friesian, and Jersey purebred cows and their respective crosses in seasonal-calving commercial farms. Journal of Dairy Science, 99, 5681-5689. https://doi.org/10.3168/jds.2015-10530

Dechow, C. D., Rogers, G. W., Cooper, J. B., Phelps, M. I., \& Mosholder, A. L. (2007). Milk, fat, protein, and somatic cell score and days open among Holstein, Brown Swiss and their crosses. Journal of Dairy Science, 90, 3542-3549. https://doi.org/10.3168/jds.2006-889

Demarco, D. (2010). La Production de carne vacuna and el stock bovino. Una relación de creciente deterioro. Retrieved from 
http://www.produccion-animal.com.ar/informacion_tecnica/origenes_evolucion_y_estadisticas_de_la_gana deria/100-LaProducciondeCarneyelStock\%20bovino.pdf.

Fohrman, M. H., McDowell, R. E., Matthews, C. A., \& Hilder, R. A. (1954). A crossbreeding experiment with dairy cattle. Technical Bulletin 1074, USDA, Washington DC, USA.

Hansen, L. B., Heins, B. J., \& Seykora, A. J. (2005). Crossbreeding: Why the interest? What to expect. In Proceedings of the 42nd Florida Dairy Production Conference, 3 May 2005, Gainesville, Florida, USA. 14-21.

Harris, B. L., Holmes, L. C., Winkelman, A. M., \& Xu, Z. Z. (1996). Comparisons between fertility and survival of strains of Holstein-Friesian cows, Jersey cows and their crosses in New Zealand. British Society of Animal Science, 26, 491-493. https://doi.org/10.1017/S0263967X00034182

Hazel, A. R., Heins, B. J., \& Hansen, L. B. (2017). Production and calving traits of Montbeliarde $\times$ Holstein and Viking Red $\times$ Holstein cows compared with pure Holstein cows during first lactation in 8 commercial dairy herds. Journal of Dairy Science, 100, 4139-4149. https://doi.org/10.3168/jds.2016-11860

Heins, B. J., Hansen, L. B., \& Seykora, A. J. (2006). Production of pure Holsteins versus crossbreds of Holstein with Normande, Montbeliarde, and Scandinavian Red. Journal of Dairy Science, 89, 2799-2804. https://doi.org/10.3168/jds.S0022-0302(06)72356-6

Heins, B. J., \& Hansen, L. B. (2012). Short communication: Fertility, somatic cell score, and production of Normande $\times$ Holstein, Montbéliarde $\times$ Holstein, and Scandinavian Red $\times$ Holstein crossbreds versus pure Holsteins during their first 5 lactations. Journal of Dairy Science, 95, 918-924. https://doi.org/10.3168/jds.2011-4523

Kargo, M., Madsen, P., \& Norberg, E. (2012). Short communication: Is crossbreeding only beneficial in herds with low management level?. Journal of Dairy Science, 95, 925-928. https://doi.org/ 10.3168/jds.2011-4707

Kirkpatrick, M., Lofsvold, D., \& Bulmer, M. (1990). Analysis of inheritance, selection, and evolution of growth trajectories. Genetics, 124, 979-993.

Laborde, D., Dutour, J. E., Lopez-Villalobos, N., Meikle, A., \& Chilibroste, P. (2014). Productive and reproductive performance of crossbred cows of North American Hosltein, New Zealand Friesian, New Zealan Jersey or Swedish Red-and-White sires and Uruguayan Holstein dams in a seasonal-calving, predominantly pasture-based system. In Proceedings of the 10th World Congress of Genetics Applied to Livestock Production. 19 August 2014, Vancouver, BC, Canada, Poster No. 812.

Lee, J. K., VanRaden, P. M., Norman, H. D., Wiggans, G. R., \& Meinert, T. R. (1997). Relationship of yield during early lactation and days open during current lactation with 305-day yield. Journal of Dairy Science, 80, 771-776. https://doi.org/10.3168/jds.S0022-0302(97)75997-6

Lopez-Villalobos, N., Garrick, D. J., Holmes, C. W., Blair, H. T., \& Spelman, R. J. (2000). Profitabilities of some mating systems for dairy herds in New Zealand. Journal of Dairy Science, 83, 144-153. https://doi.org/10.3168/jds.S0022-0302(00)74865-X

Lopez-Villalobos, N., Berry, D. P., Horan, B., Buckley, F., Kennedy, F., O’Donovan, M., Shalloo, L., \& Dillon, P. (2008). Genetics of residual feed intake in Irish grazing dairy cows. In Proceedings of the New Zealand Society of Animal Production, 68, 97-100.

Macciotta, N. P. P., Vicario, D., \& Cappio-Borlino, A. (2005). Detection of different shapes of lactation curve for milk yield in dairy cattle by empirical mathematical models. Journal of Dairy Science, 88, 1178-1191. https://doi.org/10.3168/jds.S0022-0302(05)72784-3

Malchiodi, F., Cecchinato, A., \& Bittante, G. (2014). Fertility traits of purebred Holsteins and 2- and 3-breed crossbred heifers and cows obtained from Swedish Red, Montbéliarde, and Brown Swiss sires. Journal of Dairy Science, 97, 7916-7926. https://doi.org/10.3168/jds.2014-8156

Mostert, B. E., Theron, H. E., \& Kanfer, F. H. J. (2003). Derivation of standard lactation curves for South African dairy cows. South African Journal of Animal Science, 33(2). http://dx.doi.org/10.4314/sajas.v33i2.3758

Oltenacu, P. A., \& Broom, D. M. (2010). The impact of genetic selection for increased milk yield on the welfare of dairy cows. Animal Welfare, 19, 39-49.

Philipsson, J., Jansson, L., \& Brannang, E. (1975). Selection index of bulls regarding economically important characters. Report of the Agricultural College of Sweden, Uppsala. 
Rincon, E. J., Schermerhorn, E. C., McDowell, R. E., \& McDaniel, B. T. (1982). Estimation of genetic effects on milk yield and constituent traits in crossbred dairy cattle. Journal of Dairy Science, 65, 848-856. https://doi.org/10.3168/jds.S0022-0302(82)82275-3

SAS Institute. (2014). SAS/STAT Software. Release 9.4. SAS Institute Inc., Cary, NC, USA.

Schaeffer, L. R. (2004). Application of random regression models in animal breeding. Livestock Production Science, 86, 35-45. https://doi.org/10.1016/S0301-6226(03)00151-9

Schukken, Y. H., Wilson, D. J., Welcome, F., Garrison-Tikofsky, L., \& Gonzalez, R. N. (2003). Monitoring udder health and milk quality using somatic cell counts. Veterinary Research, 34, 579-596. https://doi.org/10.1051/vetres:2003028

Silvestre, A. M., Martins, A. M., Santos, V. A., Ginja, M. M., \& Colaço, J. A. (2009). Lactation curves for milk, fat and protein in dairy cows: A full approach. Livestock Science, 122, 308-313. https://doi.org/10.1016/j.livsci.2008.09.017

Sørensen, M. K., Norberg, E., Peterson, J., \& Christensen, L. G. (2008). Invited review: Crossbreeding in dairy cattle: A Danish perspective. Journal of Dairy Science, 91, 4116-4128. https://doi.org/10.3168/jds.2008-1273

Swalve, H. H., Bergk, N., \& Solms-Lich, P. H. (2008). Kreuzungszucht beim milchrind-ergebnisse aus einem prazisbetrieb. Züchtungskunde, 80, 429-442.

Touchberry, R. W. (1992). Crossbreeding effects in dairy cattle: The Illinois experiment, 1949 to 1969. Journal of Dairy Science, 75, 640-667. https://doi.org/10.3168/jds.S0022-0302(92)77801-1

Vance, E. R., Ferris, C. P., Elliott, C. T., McGettrick, S. A., \& Kilpatrick, D. J. (2012). Food intake, milk production performance, and tissue changes of Holstein-Friesian and Jersey $\times$ Holstein-Friesian dairy cows within a medium-input grazing system and a high input total confinement system. Journal of Dairy Science, 95, 1527-1544. https://doi.org/10.3168/jds.2011-4410

Vargas, B., Koops, W. J., Herrero, M., \& Van Arendonk, J. A. M. (2000). Modeling extended lactations of dairy cows. Journal of Dairy Science, 83, 1371-1380. https://doi.org/10.3168/jds.S0022-0302(00)75005-3

Weigel, K. A., \& Barlass, K. A. (2003). Results of a producer survey regarding crossbreeding on US dairy farms. Journal of Dairy Science, 86, 4148-4154. https://doi.org/10.3168/jds.S0022-0302(03)74029-6

\section{Copyrights}

Copyright for this article is retained by the author(s), with first publication rights granted to the journal.

This is an open-access article distributed under the terms and conditions of the Creative Commons Attribution license (http://creativecommons.org/licenses/by/3.0/). 